\title{
MEDIEVAL PAINTED DECORATION IN ST MICHAEL'S CHURCH IN MIHKLI, ESTONIA
}

St Michael's church in Soontagana, later Mihkli, in the medieval bishopric of Osilia, was first mentioned in written sources in 1528. The church must have existed much earlier, but the exact construction date of the present stone building of St Michael's in Mihkli is unknown. Recent studies have shown that it was constructed in two stages: at first a simple building with beamed ceiling was erected, and at a later date (possibly around 1500) vaulting was added over the first chancel and the nave. ${ }^{2}$ The initial plain building must have been in use for some time since its interior was plastered and whitewashed. Traces of this plaster have been preserved above the present vaults.

After the construction of the vaults, the church was re-plastered and decorated. It should be noted that the ribs were built irregularly of brick and stone; their final rectangular form was achieved through plaster moulding.

In August 2013, preliminary investigations were carried out in the church to record the painted decorations of the interior. Only small sample areas were uncovered, but they were sufficient to reveal the

DOI: http://dx.doi.org/10.12697/BJAH.2013.6.07

1 For discussion of the written sources see Ain Mäesalu, "Uusi andmeid Mihkli kiriku vanemast ajaloost", Õpetatud Eesti Seltsi aastaraamat = Annales Litterarum Societatis Esthonicae 2011 (Tartu, 2012), 129-130, 138-144 and Kaur Alttoa, "Die St. Michaeliskirche in Wiek - eine Wehrkirche?", Baltic Journal of Art History, 5 (2013), 179-200.

2 See Alttoa, "Die St. Michaeliskirche in Wiek - eine Wehrkirche?" and Ain Mäesalu, Martin Malve, "Archaeological excavations on the vaults of Mihkli church, Pärnu county", Arheoloogilised välitööd Eestis = Archaeological fieldwork in Estonia 2011 (Tallinn: National Heritage Board, 2012), 209-216. 
historical colour schemes. The richest decoration adorns the earliest paint layer. The later layers are simpler, representing either monochrome paint covering all of the walls and vaults, or a combination of two colours.

The vaulted church was first painted when its plaster had not yet dried. The outlines of the composition were drawn into the plaster with a sharp instrument; a ruler and compass were likewise used. The executor of this work had some trouble in measuring and achieving symmetry in the composition. Then red, black (grey) and white paints in different shades were applied loosely following the drawn outlines.

This decorative scheme had the aim of enhancing the architectural features of the church; no figurative paintings were found. The structural elements of the vaults - bosses, ribs and corbels - are painted; the decoration spreads around the bosses and onto the walls. The background is creamy white, and all of the ribs are painted grey with white-redwhite 'joints' at somewhat uneven distances $(65$ to $90 \mathrm{~cm}$ ). The red band of these 'joints' is continued casually onto the vault web. The diagonal ribs in the nave spring from small triangular corbels painted grey and surrounded by a wide red line. The transverse and ridge ribs in the eight-partite chancel vault end in grey painted pendants, also with a red contour (fig. 1).

The centres of the vaults are decorated differently in the chancel and nave. The former has several circles of 'joints' painted in the centre, the innermost having the form of a small eight-petalled flower (fig. 2). The eastern nave vault has a circled cross on the boss, five curved 'joints' on the ribs, close together, and heart-shaped motifs between the ribs, forming a large (diameter approx. one meter) irregular flower-like composition (fig. 3). The 'petals' have red outlines, random brush strokes and dots on them, and tassels between the 'petals'.

The style and execution of the paintings are clearly vernacular and were made by an inexperienced hand. Interestingly, this corresponds to the rough construction of the vaulting. It seems that both the masons and decorators were not skilled professionals but rather local masters following earlier examples without fully comprehending their sources. However, their ambition and pride in the achievement can still be sensed in the result.

In Scandinavia, such vernacular murals have been long studied. They have been called 'primitive paintings' in earlier research, but in the more 


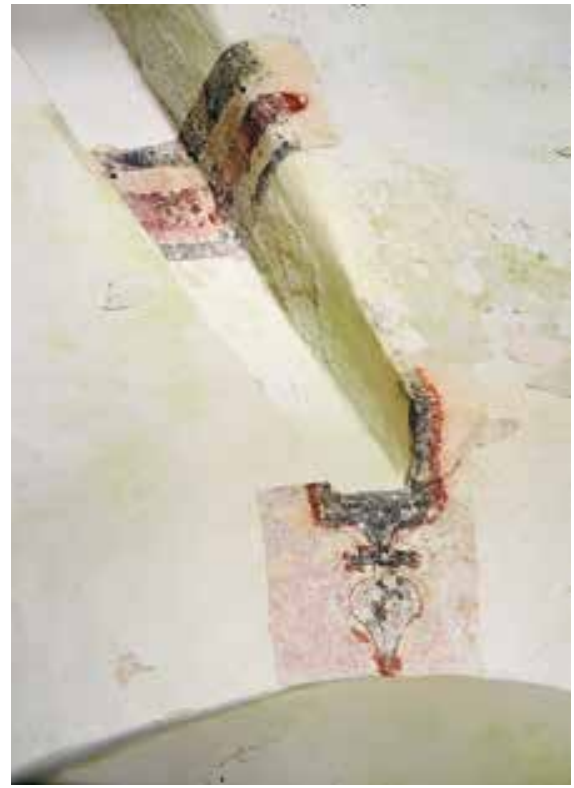

Fig. 1. A painted pendant completing the rib in the chancel. Photo by Peeter Säre.

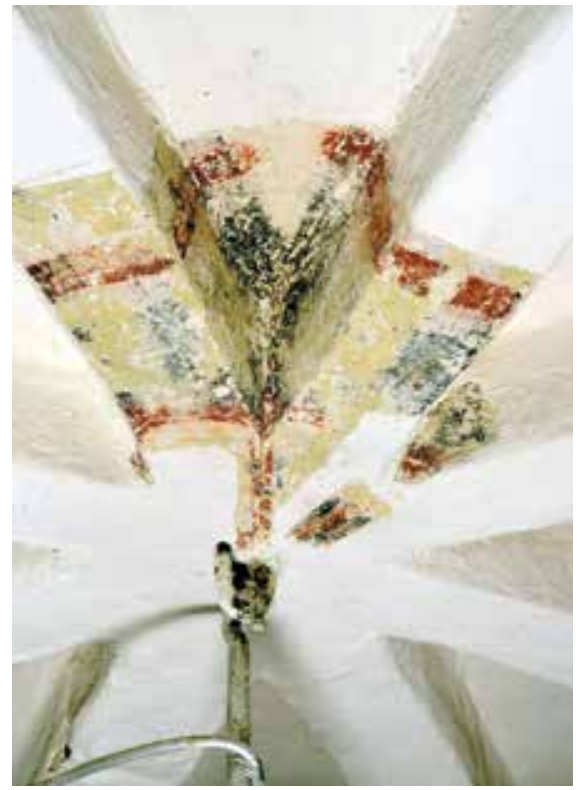

Fig. 2. Decoration in the centre of the chancel vault. Photo by Peeter Säre.

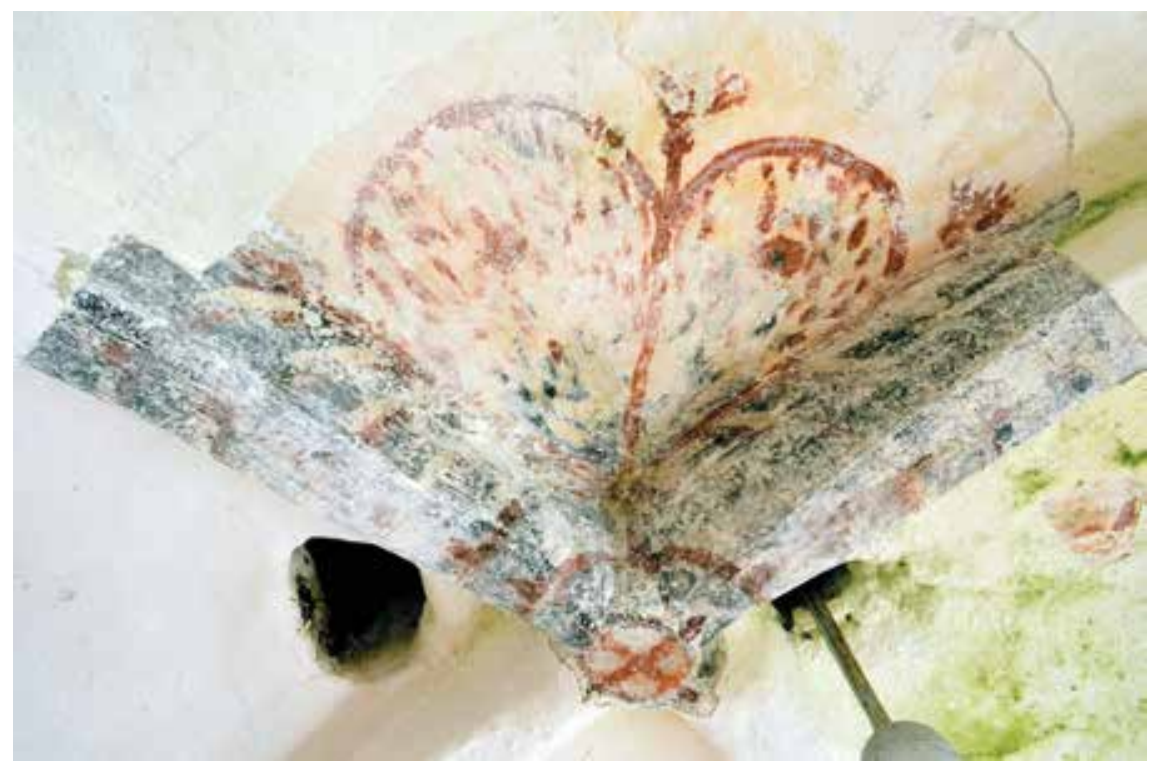

Fig. 3. Decoration in the centre of the eastern vault of the nave. Photo by Peeter Säre 
recent studies it has been suggested that these murals could have been executed by the medieval church builders as the first set of decoration, especially on the vaults. ${ }^{3}$ The paintings in Mihkli's St. Michael's might have been executed in a similar context.

Since the dating of the construction stages of the church is uncertain and no written sources have survived, there is no firm evidence for dating the painted decoration. In terms of relative chronology, these paintings are concurrent with the erection of the vaults, since they were executed on the first plaster of the vaults when it had not yet dried. When compared to other architectural murals in the same region, ${ }^{4}$ it can be suggested that the ones in Mihkli's St Michael's are late medieval. Kaur Alttoa has proposed that the vaults were erected around $1500^{5}$ and this is a plausible dating for the murals.

The discovery of these paintings is a valuable addition to the corpus of medieval church paintings in Estonia and enriches the understanding of the medieval world. The current introduction serves the purpose of publishing this find, and further analysis (including technical investigation) will follow in future studies.

Anneli Randla: Medieval painted decoration in St Michael's in MihKLi, Estonia

KeyWords: Medieval MURALs, CHURCH DeCORATION, PAINT ReSEARCH, TECHNICAL STUDIES OF ART

Summary:

Recent studies in the medieval St Michael's Church in Mihkli, in western Estonia, have shown that the stone church was constructed in two stages: at first a simple building with wooden ceiling was erected, and

3 See for example Helena Edgren, "Primitive' paintings: the visual world of populous rusticus", History and Images: Towards a New Iconology, ed. by Axel Bolvig and Philip Lindley (Turnhout: Brepols, 2003), 301-322 and Katja Fält, Wall Paintings, Workshops, and Visual Production in the Medieval Diocese of Turku from 1430 to 1540, Suomen Muinaismuistoyhdistyksen Aikakauskirja 120, (Helsinki, 2012). 4 For example, in the churches in Martna, Pöide, Muhu and Karja. For an overview see Anneli Randla, "Medieval wall paintings in Estonia. History and current state of research", Archaeology and History of Churches in Baltic Region, ed. by Joakim Hansson and Heikki Ranta (Visby: Gotland University Press, 2011), 237-255.

5 Alttoa, "Die St. Michaeliskirche in Wiek - eine Wehrkirche?", 193. 
at a later date (possibly around 1500) stone vaulting was added over the first chancel and the nave. In August 2013, preliminary investigations were undertaken to study the painted decoration of the inner walls and vaults of the church. The small sample areas uncovered were sufficient to reveal several historical colour schemes. The richest decoration is contemporary with the first plastering of the vaults since the plaster was still moist when the paint was applied. The decoration is vernacular in character and its aim is to enhance the architectural features of the building. Thus the ribs and corbels of the vaults are painted but the decoration is extended to flat surfaces as well. For example painted pendants in grey and red adorn the ends of the ribs of the eight-partite vault of the chancel. The largest composition was discovered in the eastern bay of the nave around the vault boss. An irregular eight-petalled red flower is formed around the boss with a cross on it. These paintings might have been executed by local church builders rather than by professional craftsmen.

CV:

Anneli Randla earned her PhD in art history at the University of Cambridge in 1999. She has worked for the National Heritage Board of Estonia for ten years. Since 2008 Randla has been an associate professor in the Department of Conservation at the Estonian Academy of Arts and currently she serves as the dean of the Faculty of Art and Culture at the academy. Her main research interests are: medieval ecclesiastical architecture, medieval murals, technical studies of art and the history of conservation. 
